УДК 631.5: 633.11, DOI 10.31210/visnyk2018.02.30

(C) 2018

Позняк В. В., асистент кафедри агрохімії

Дніпровський державний аграрно-економічний університет

\title{
ЕФЕКТИВНІСТЬ ЗАСТОСУВАННЯ РЕГУЛЯТОРА РОСТУ «ХЛОРМЕКВАТ-ХЛОРИД» У ПОСІВАХ ПШЕНИЦІ ОЗИМОЇ ЗАЛЕЖНО ВІД РІВНЯ УДОБРЕННЯ
}

\section{Рецензент - доктор сільськогосподарських наук А. Д. Гирка}

Наведено результати трирічних досліджень впливу регулятора росту «Хлормекват-хлорид» у поєднанні з дією трьох варіантів удобрення трунту на picm, розвиток $i$ формування урожаю зерна пшенииею озимою сорту Співанка в разі вирощування ї̈ на чорноземі звичайному. Найбільи ефективними варіантами застосування «Хлормекват-хлориду» виявились: обробка посівів цимм регулятором росту восени $i$ одноразова обробка навесні, обробка посівів регулятором росту восени і дворазова обробка навесні. Інкрустачія насіння «Хлормекват-хлоридом» перед сівбою, а також інкрустація з одноразовою обробкою посівів навесні теж позитивно впливали на формування урожаю зерна. Встановлено найоптимальнішу доза добрив для ефективного застосування «Хлормекват-хлориду».

Ключові слова: пшениця озима, удобрення грунту, регулятор росту «Хлормекват-хлорид», структура урожаю, урожайність.

Постановка проблеми. Підвищення урожайності пшениці озимої є однією 3 важливих проблем під час вирощування цієї цінної культури, особливо в степовій зоні України, де вона є провідною продовольчою культурою і займає в структурі зернового клину половину посівних площ. Стабілізація виробництва якісного зерна пшениці озимої на високому рівні, що обумовлений генетичним потенціалом культури, досягається за рахунок удосконалення технології іiі вирощування, яка дасть змогу не тільки формувати високопродуктивні агроценози, максимально стійкі до стресових погодних явищ, але і забезпечить підвищення економічної та енергетичної ефективності, а також підтримання екологічної безпеки довкілля $[5,7,8]$.

Численними дослідженнями попередніх років доведено, що інтенсивне використання чорноземних грунтів призвело до втрати ними значної кількості органічної речовини та елементів живлення [5, 7, 10]. Тому в умовах Степу України важливою складовою отримання високого врожаю пшениці озимої є оптимізації системи живлення посівів цієї культури, в результаті якої відбувається найбільш повне забезпечення потреб рослин у поживних елементах протягом усього періоду їх вегетації $[3,6]$.
Іншим чинником підвищення урожайності пшениці озимої є застосування сучасних регуляторів росту рослин, широке впровадження яких $\epsilon$ резервом інтенсифікації виробництва зерна пшениці озимої. Регулятори росту рослин є аналогами натуральних фітогормонів, що імітують дію природного гормону або впливають на ріст рослин через зміну всього гормонального статусу $[1,4]$.

Сучасний ринок пропонує низку препаратів, які впливають на рослини пшениці озимої як ріст-регулятори. Зокрема, це «Хлормекватхлорид» - найпоширеніший з препаратів антигіберелінової дії, який сприяє зменшенню висоти стебла, потовщенню стінок соломини, збільшенню міцності нижніх міжвузлів. Одночасно $з$ цим, він прискорює швидкість утворення хлорофілу в листі та посилює розвиток кореневої системи. «Хлормекват-хлорид» класифікується як препарат із низьким рівнем ризику для довкілля та здоров'я людини. Під час його розпаду в рослинах утворюються природні метаболіти (холін та бетаїн), що обумовлює відсутність негативного впливу на екологічний стан довкілля. В результаті дії «Хлормекват-хлориду» посилюється стійкість рослин до несприятливих погоднокліматичних умов, збільшується продуктивність рослин, прискорюється та підвищується якість збирання урожаю $[1,2,9]$.

Аналіз останніх досліджень і публікацій, у яких започатковано розв'язання проблеми. Пошук шляхів оптимізації дії агротехнічних факторів на урожайність пшениці озимої завжди був і $\epsilon$ актуальним для агрономічної науки i практики. Вивченню питань удосконалення технології вирощування пшениці озимої приділялось багато уваги визначними вченимиаграріями. Значний внесок у розробку цього питання зробили П. П. Лук'яненко, В. М. Ремесло, А. І. Задонцев, Г. Р. Пікуш, І. С. Годулян, В. І. Бондаренко, А. І. Носатовський, Л. А. Животков, А. В. Черенков та інші.

Вивченню впливу рівня удобрення грунту на ріст, розвиток і формування урожаю рослинами 


\section{СТОРІНКА МОЛОДОГО ВЧЕНОГО}

пшениці озимої приділяється багато уваги з урахуванням необхідності дослідження нових сучасних сортів пшениці озимої, певних змін у технології їі вирощування, можливості застосування нових видів мінеральних добрив з урахуванням грунтово-кліматичних умов, в яких розміщені посіви $[3,5,6]$. Активно досліджуються можливості застосування рістрегулюючих речовин під час вирощування зернових культур [1, 4, 9]. Але загалом досліджень стосовно впливу «Хлормекват-хлориду» на рослини пшениці озимої в останні роки було небагато, а в попередні роки вони були проведені на сортах пшениці, які вже виключені 3 Державного реєстру сортів рослин, придатних для поширення в Україні.

На даний момент у науковій літературі не висвітлені питання комплексного впливу цих двох факторів на новий перспективний для зони Степу сорт пшениці озимої Співанка. В зв’язку 3 цим, вирішення питання щодо виявлення умов позитивного впливу взаємодії оптимальної системи удобрення грунту та обробки насіння і посівів регулятором росту «Хлормекват-хлорид» на формування урожаю пшениці озимої сорту Співанка є актуальним і важливим науковим завданням.

Метою досліджень було встановлення ефективності комплексного застосування обробки насіння і посівів пшениці озимої сорту Співанка регулятором росту «Хлормекват-хлорид» за різних норм мінеральних добрив на формування урожаю зерна в разі вирощування іï на чорноземі звичайному в умовах Північного Степу.

Завдання досліджень: вивчення комплексного впливу застосування «Хлормекват-хлориду» та різних норм мінеральних добрив на ріст і розвиток пшениці озимої сорту Співанка протягом усієї вегетації, а також виявлення особливостей формування iï урожаю шляхом аналізу біометричних показників, що характеризують розвиток рослин, структури урожаю та рівня урожайності контрольних та дослідних ділянок посівів.

Матеріали та методи досліджень. Дослідження проводились на дослідному полі Навчальнонаукового центру ДДАЕУ протягом 2012-2013, 2013-2014 і 2014-2015 вегетаційних років у двофакторному польовому досліді. Грунт - чорнозем звичайний малогумусний легкосуглинковий з низьким вмістом легкогідролізованого азоту, високим - рухомого фосфору та середнім - обмінного калію. Схема досліду включала такі фактори: А застосування препарату «Сінхроні SL» фірми «Green Express», діючою речовиною якого $\epsilon$ «Хлормекват-хлорид», яким оброблялось насіння перед сівбою (інкрустація) або рослини - згідно 3 рекомендаціями - восени на початку фази кущення, а також навесні - після відновлення весняної вегетації та на початку фази виходу в трубку; В норми добрив $\left(\mathrm{P}_{30} \mathrm{~K}_{20}+\mathrm{N}_{30}, \mathrm{~N}_{30} \mathrm{P}_{60} \mathrm{~K}_{30}+\mathrm{N}_{30}\right.$, $\left.\mathrm{N}_{60} \mathrm{P}_{90} \mathrm{~K}_{60}+\mathrm{N}_{30}+\mathrm{N}_{30}\right)$. Попередник - чорний пар. Площа облікової ділянки - 33 м², повторність триразова, розміщення ділянок - систематичне. Погодні умови в роки проведення досліджень в основному були характерними для зони Степу. Сприятливими для росту, розвитку і формування урожаю пшениці озимої були умови вегетації 2013-2014 і 2014-2015 рр., менш сприятливими 2012-2013 роки.

Результати досліджень. Згідно зі схемою досліду, у контрольному варіанті рослини пшениці озимої сорту Співанка не піддавались обробці ретардантом. Восени досліджувані варіанти були такими: 1 - контроль без обробки «Хлормекватхлоридом»; 2 - інкрустація насіння «Хлормекват-хлоридом» перед сівбою, 3 - обробка посівів «Хлормекват-хлоридом» восени на початку фази кущення. Рослини пшениці озимої вирощувались на трьох фонах добрив: $\mathrm{P}_{30} \mathrm{~K}_{20}, \mathrm{~N}_{30} \mathrm{P}_{60} \mathrm{~K}_{30}$, $\mathrm{N}_{60} \mathrm{P}_{90} \mathrm{~K}_{60}$ (з додатковим внесенням азоту навесні до кожного 3 фонів живлення - $\mathrm{N}_{30}$ або $\mathrm{N}_{60}$ згідно зі схемою досліду).

У середньому за три роки проведення дослідів протягом осінньої вегетації рослин пшениці озимої суттєвої різниці в біометричних показниках іiі розвитку залежно від дії регулятора росту не спостерігалось. Загалом ріст і розвиток рослин залежав від рівня вологозабезпечення, температурного режиму та тривалості осінньої вегетації. Площа живлення, а також фон удобрення мали менше значення, тому що рослини в цей період були слабко розвинені і ще не конкурували між собою за поживні елементи та воду.

На час припинення осінньої вегетації висота рослин у середньому становила 19,5-21,1 см. Проте в окремі роки проведення дослідів різниця у висоті була досить помітною: у 2012 р. цей показник коливався в межах 24,7-28,3 см, а у 2013 р. - 14,517,7 см. Суттєвої різниці у висоті контрольних рослин і тих, що піддавались дії ретарданту, не відмічено (різниця 3,1 \% - в межах похибки досліду). Вплив внесених добрив у цей період теж був не суттєвим (у межах 2-4 \%). Це пояснюється тим, що на початкових етапах розвитку пшениці рослинам вистачало поживних речовин грунту, навіть на мінімальному фоні удобрення.

У середньому за 3 роки досліджень показники маси 100 абсолютно сухих рослин у цей період знаходились у межах 10,5-11,7 г (з варіаціями від 6,3-7,5 г у 2013 р. до 13,1-17,7 г у 2012 р.). Різниця у масі контрольних рослин і рослин, обробле- 
них регулятором росту, в цей період не відмічена. Пшениця, що росла на мінімальному фоні удобрення, мала масу в середньому на 8,5 \% меншу за рослини, що розвивались на ділянках із більшим рівнем забезпечення поживними речовинами.

Глибина залягання вузла кущіння змінювалась у незначних межах: від 2,2 до 2,8 см (в 2012 р. - 1,4 2,3 см, у 2013 і 2014 pp. -2,1-3,5 см).

Деякий вплив «Хлормекват-хлориду» спостерігався у випадку застосування доз удобрення $\mathrm{N}_{30} \mathrm{P}_{60} \mathrm{~K}_{30}$ i $\mathrm{N}_{60} \mathrm{P}_{90} \mathrm{~K}_{60}$ (збілышення глибини залягання вузла кущіння під його дією порівняно $з$ контролем становило 0,3 та 0,5 см відповідно). Кількість стебел та вузлових коренів на одній рослині в період припинення осінньої вегетації не залежала від дії досліджуваних факторів.

На початку весни було проведено внесення додаткової дози азоту $\left(\mathrm{N}_{30}\right.$ - по тало-мерзлому грунту) на всіх варіантах удобрення. В цей період у рослин, насіння яких було інкрустоване ретардантом, і тих, посіви яких були оброблені «Хлормекват-хлоридом» восени в фазі кущення, спостерігалась незначна тенденція до дещо більшої висоти рослин (у межах похибки досліду) порівняно 3 контролем. Це пояснюється тим, що вимірювалася довжина живої здорової частини листка, яка менше постраждала в оброблених ретардантом рослин у процесі перезимівлі. Подальші спостереження показали, що вже в кінці фази кущення ця різниця зникає і висота рослин пшениці озимої, що зазнала впливу регулятора росту, стає меншою, ніж у контрольних рослин без обробки ретардантом (у середньому на 5-7 см). Пшениця, що росла на мінімальному фоні удобрення $\left(\mathrm{P}_{30} \mathrm{~K}_{20}+\mathrm{N}_{30}\right)$, виявилась на 7 \% нижчою за ту, що отримувала максимальну кількість поживних речовин.

Застосування «Хлормекват-хлориду» обумовило збільшення маси 100 абсолютно сухих рослин у середньому на 12,9 \%. Залежно від варіанту удобрення спостерігалось збільшення маси рослин зі збільшенням дози внесених добрив (на 14,5 \%). Найбільшу висоту і масу мали рослини пшениці озимої, що були оброблені ретардантом i росли на більш високому фоні добрив.

У цей період на кількість живих або відмерлих стебел на одній рослині досліджувані фактори не мали помітного впливу. Це стосується і такого показника як кількість на рослині нових вузлових коренів. Водночас більше надземної маси на час відновлення весняної вегетації збереглось у рослин, що восени піддавались обробці «Хлормекват-хлоридом» (на 9,6 \%). На цей показник позитивно впливало і збільшення кількості внесених 3 мінеральними добривами поживних речовин - надземної маси за цих умов збереглося на $6,5 \%$ більше.

Суттєвої різниці між рослинами, насіння яких було інкрустоване ретардантом перед сівбою, i тими, посіви яких були оброблені «Хлормекватхлоридом» восени в фазі кущення, по всіх показниках, що аналізувалися, не відмічалось.

У фазі весняного кущення озимої пшениці у варіанті $з$ максимальною дозою мінеральних добрив посіви були підживлені азотними добривами (дозою $\mathrm{N}_{30}$ ). Протягом весняно-літньої вегетації була проведена додаткова обробка ретардантом частини посівів пшениці озимої (одноразова або дворазова згідно зі схемою досліду). Отже, аналізувались наступні варіанти застосування ретарданту: контроль (без обробки); інкрустація ретардантом перед сівбою; інкрустація ретардантом перед сівбою + одноразова обробка посівів навесні; обробка посівів ретардантом восени; обробка посівів ретардантом восени + одноразова обробка навесні; обробка посівів ретардантом восени + дворазова обробка навесні.

Встановлено, що застосування регулятора росту «Хлормекват-хлорид» та застосовані дози добрив впливали на ріст, розвиток і формування урожаю посівами пшениці озимої у всі роки проведення досліджень. Цей вплив добре проявився під час аналізу елементів структури отриманого урожаю.

В середньому за роки досліджень кількість рослин на одиниці площі посівів найменшою, - незалежно від фону удобрення, - виявилась у контрольних рослин, що не піддавались обробці ретардантом (186-193 шт./ м²). У цьому варіанті і вплив добрив був незначним (5,5 \%). Слід зазначити, що різні варіанти обробки ретардантом обумовили збільшення кількості рослин на метрі квадратному в межах лише 1,9-4,3 \%. Математично достовірної різниці між варіантами по даному показнику не виявлено.

Кількість усіх стебел на квадратному метрі посівів у контрольних рослин без обробки регулятором росту була дещо вищою, ніж у оброблених «Хлормекват-хлоридом» рослин (588,5-598,3 проти 549,9-586,9 шт./ м $^{2}$ по всіх варіантах удобрення грунту.

Вплив ретарданту виразився у зменшенні кількості стебел у разі вирощування на мінімальному фоні добрив $\left(\mathrm{P}_{30} \mathrm{~K}_{20}+\mathrm{N}_{30}\right)$ на 3,9-6,6 \%, на максимальному $\left(\mathrm{N}_{60} \mathrm{P}_{90} \mathrm{~K}_{60}+\mathrm{N}_{60}\right)$ - на 5,4-6,8 \%. Разом 3 тим, продуктивних стебел більше сформувалось у рослин, на які впливала обробка ретардантом (збільшення становило від 2,9 до 4,8 \% порівняно 3 контролем). Значної переваги одного 3 варіантів застосування ретарданту над іншими по цьому показнику не виявлено. 


\section{СТОРІНКА МОЛОДОГО ВЧЕНОГО}

Продуктивна кущистість у контрольних рослин (без обробки ретардантом) становила 2,80-2,84, вона дещо збільшувалась зі збільшенням рівня удобрення. В таких же межах цей показник знаходився у рослин, які оброблялись ретардантом восени. В разі обробки рослин «Хлормекватхлоридом» восени і одноразово навесні показники продуктивної кущистості становили 2,83-2,89 (цей показник найбільшим був у рослин, що вирощувались на фоні мінімальної та середньої дози добрив - 2,89). У рослин, які піддавались обробці ретардантом восени і дворазовій обробці навесні найбільшим цей показник також виявився на фоні мінімальної та середньої дози добрив 2,84 і 2,87. Рослини, інкрустовані регулятором росту перед сівбою, вищий рівень показників продуктивної кущистості $(2,84$ і 2,87) мали в разі вирощування на фоні середньої $\left(\mathrm{N}_{30} \mathrm{P}_{60} \mathrm{~K}_{30}+\mathrm{N}_{30}\right)$ та високої норми $\left(\mathrm{N}_{60} \mathrm{P}_{90} \mathrm{~K}_{60}+\mathrm{N}_{60}\right)$ удобрення мінеральними добривами. Додаткова обробка навесні рослин, насіння яких було інкрустоване ретардантом перед сівбою, не вплинуло на продуктивну кущистість порівняно 3 посівами інкрустованим насінням (без додаткової обробки навесні).

Маса зерна $з$ одного колоса пшениці озимої коливалась у межах 0,86-1,12 г. Найменшим цей показник був у контрольному варіанті (0,87-0,96 г) і у варіанті 3 додатковою дворазовою обробкою навесні посівів, що піддавались дії «Хлормекватхлориду» восени (0,79-0,84 г); одноразова весняна обробка регулятором росту забезпечила формування насіння 3 одного колосу вагою 0,86-1,06 г; інкрустація насіння перед сівбою - 1,03-1,12 г; інкрустація 3 додатковою обробкою навесні 0,95-1,12 г. Чіткої залежності від фону удобрення по цьому показнику виявлено не було.

Маса 1000 зерен пшениці озимої найменшою була у контрольних рослин та у рослин, інкрусто- ваних ретардантом перед сівбою - на фоні мінімальної та середньої дози добрив - (42,70-43,63 г). У рослин, оброблених «Хлормекват-хлоридом» восени і тих, що крім осінньої обробки одноразово оброблялись ретардантом навесні, маса 1000 зерен була найбільшою (45,47-47,20 г). Відмічена тенденція до збільшення маси 1000 зерен зі збільшенням застосованої дози добрив (у межах 1,7-2,2 г) в усіх варіантах досліду.

Кінцевим результатом, що характеризує ефективність застосованих агротехнічних прийомів під час вирощування пшениці озимої, $є$ рівень іiі урожайності (див. табл.).

Складні погодні умови вегетації 2012-2013 pp. обумовили отримання найнижчого за роки досліджень урожаю пшениці. В середньому по всіх варіантах досліду він становив 4,49 т/га, в той час як у 2013-2014 і 2014-2015 вегетаційних роках - 6,33 і 6,56 т/га відповідно. Влітку 2013 р. найнижчий урожай зерна пшениці озимої в досліді було зібрано 3 контрольних ділянок (без обробки регулятором росту) - 3,93-4,47 т/га залежно від фону живлення. Така закономірність спостерігалась у всі роки досліджень. Обробка ретардантом восени або інкрустація насіння перед сівбою забезпечили формування урожаю 4,28-4,66 т/га. Найбільший урожай цього року отримано за максимальної дози добрив у варіанті з інкрустацією насіння ретардантом перед сівбою 3 одноразовою обробкою посівів навесні (4,88 т/га) та у варіантах з обробкою посівів ретардантом восени i одноразовою або дворазовою обробкою «Хлормекват-хлоридом» навесні (4,72 і 4,88 т/га відповідно).

Найбільш ефективні варіанти застосування регулятора росту обумовили зростання урожаю зерна на найбільшому фоні удобрення на 5,6$9,2 \%$.

\section{Урожайність пшениці озимої залежно від фону жсивлення та застосування}

регулятора росту, $\mathrm{m} / 2$ a

\begin{tabular}{|c|c|c|c|c|c|c|c|c|c|}
\hline \multirow{4}{*}{$\begin{array}{c}\text { Варіант застосування } \\
\text { ретарданту (А) }\end{array}$} & \multicolumn{9}{|c|}{ Роки дослідів } \\
\hline & \multicolumn{3}{|c|}{2013} & \multicolumn{3}{|c|}{2014} & \multicolumn{3}{|c|}{2015} \\
\hline & \multicolumn{9}{|c|}{ Варіант удобрення грунту (В) } \\
\hline & $1 *$ & $2 *$ & 3* & $1 *$ & $2 *$ & $3 *$ & $1 *$ & $2 *$ & $3 *$ \\
\hline Контроль & 3,93 & 4,25 & 4,47 & 5,64 & 6,11 & 6,38 & 5,86 & 6,17 & 6,52 \\
\hline Ретардант осінь & 4,28 & 4,56 & 4,62 & 5,88 & 6,46 & 6,65 & 6,25 & 6,55 & 6,83 \\
\hline Ретардант (осінь + весна) & 4,27 & 4,60 & 4,72 & 6,05 & 6,56 & 6,82 & 6,48 & 6,67 & 6,98 \\
\hline Ретардант (осінь + весна + весна) & 4,38 & 4,62 & 4,81 & 6,14 & 6,68 & 6,79 & 6,54 & 6,72 & 7,06 \\
\hline Ретардант інкрустація & 4,32 & 4,52 & 4,66 & 5,78 & 6,39 & 6,55 & 6,20 & 6,45 & 6,75 \\
\hline Ретардант інкрустація + весна & 4,37 & 4,63 & 4,88 & 5,86 & 6,59 & 6,57 & 6,42 & 6,64 & 6,92 \\
\hline $\begin{array}{l}H I P_{0,05}(A) \\
H I P_{0,05}(B) \\
H I P_{0,05}(A B)\end{array}$ & \multicolumn{3}{|c|}{0,12} & & $\begin{array}{l}0,18 \\
0,21 \\
0,30 \\
\end{array}$ & & & $\begin{array}{l}0,21 \\
0,22 \\
0,33 \\
\end{array}$ & \\
\hline
\end{tabular}

Примітка: * $1-\mathrm{P}_{30} \mathrm{~K}_{20}+\mathrm{N}_{30} ; 2-\mathrm{N}_{30} \mathrm{P}_{60} \mathrm{~K}_{30}+\mathrm{N}_{30} ; 3-\mathrm{N}_{60} \mathrm{P}_{90} \mathrm{~K}_{60}+\mathrm{N}_{60}$. 
Найменше зерна пшениці отримано на мінімальному фоні удобрення - в середньому по всіх варіантах обробітку ретардантом - 4,26 т/га (на середньому фоні - 4,53; на максимальному 4,69 т/га).

Умови вегетації 2013-2014 рр. були сприятливими для формування урожаю зерна пшениці озимої. Найменшим він закономірно був на контрольних ділянках $(5,64-6,38$ т/га). Найвищий рівень урожаю отримано на максимальному фоні живлення у варіантах з обробкою посівів пшениці регулятором росту восени $(6,65$ т/га) і обробкою посівів восени і одноразовою або дворазовою обробкою «Хлормекват-хлоридом» навесні $(6,82-6,79$ т/га), дещо нижчий в обох варіантах 3 інкрустацією насіння перед сівбою $(6,48$ і 6,57 т/га). У випадку застосування найменшої та середньої дози добрив більший урожай сформувався у варіанті з обробкою посівів восени і дворазовою - навесні $(6,14-6,68$ т/га). Загалом різні варіанти застосування «Хлормекват-хлориду» на досліджуваних фонах удобрення забезпечили збільшення врожаю на 2,5-9,3\%.

У сприятливому для пшениці 2015 р. найменшим урожай зерна був у варіантах без обробки ретардантом $(5,86-6,52$ т/га). Найбільш ефективно обробка регулятором росту діяла на фоні середньої та максимальної дози добрив: обробка посівів «Хлормекват-хлоридом» восени збільшила урожай зерна на 7,1-8,1 \% (урожай становив 6,55-6,83 т/га); обробка посівів пшениці регулятором росту восени і одноразова або дворазова обробка навесні - на 8,3-8,9 \% (урожай 6,67-6,98 і 6,72-7,06 т/га відповідно), інкрустація насіння і обробка посівів навесні - на 6,137,6 \% (урожай - 6,64-6,92 т/га).

Висновок. Обробка насіння або посівів пшениці озимої регулятором росту «Хлормекватхлорид» впливала на ріст, розвиток і формування урожаю зерна протягом весняно-літньої вегетації у випадку застосування всіх досліджуваних

\section{БІБЛІОГРАФІЯ}

1. Груздев Л. Г. Совместное применение ретардантов, гербицидов и удобрений под зерновые // Химия в сельском хозяйстве. -1985 . - №1. - C. 9-17.

2. Каленська С. М. Регулятори росту в інтенсивних технологіях вирощування зернових культур // Регулятори росту рослин у рослинництві. К. : Агроресурс», 1998. - С. 65-69.

3. Коваленко В. Ю., Чабан В. І. Раціональне використання добрив під озиму пшеницю // Бюл. Ін-ту зерн. господарства УААН. Дніпропетровськ, 2002. - №4. - С. 17-21.

4. Лихочвор В. Застосування регуляторів росту варіантів удобрення грунту. Закономірно вищий рівень урожаю отримано на фоні найбільш високої $\left(\mathrm{N}_{60} \mathrm{P}_{90} \mathrm{~K}_{60}+\mathrm{N}_{30}+\mathrm{N}_{30}\right)$ та середньої $\left(\mathrm{N}_{30} \mathrm{P}_{60} \mathrm{~K}_{30}+\mathrm{N}_{30}\right)$ дози добрив. Застосування різних варіантів обробки насіння та посівів пшениці озимої ретардантом «Хлормекват-хлорид» забезпечило збільшення врожаю зерна в межах $3,4-11,6 \%$.

Найбільш ефективними варіантами застосування «Хлормекват-хлориду» виявились: обробка регулятором росту восени і одноразова обробка навесні, обробка регулятором росту восени і дворазова обробка навесні. Обидва варіанти з інкрустацією насіння ретардантом перед сівбою і інкрустацією насіння та одноразовою обробкою посівів навесні теж позитивно впливали на формування урожаю зерна пшениці озимої.

Різниця між варіантами 3 одноразовою або дворазовою обробкою «Хлормекват-хлоридом» додатково до обробки посівів восени виявилась незначною (в межах похибки досліду). Це слід враховувати виробникам, оскільки на дворазову обробку необхідно виділяти додаткові кошти, які можуть не окупитись збільшенням урожаю у несприятливих для формування високого урожаю зерна погодних умовах.

Застосування підвищеної дози добрив $\left(\mathrm{N}_{60} \mathrm{P}_{90} \mathrm{~K}_{60}+\mathrm{N}_{30}+\mathrm{N}_{30}\right)$ у комбінації з різними варіантами обробки регулятором росту не забезпечило значного збільшення урожаю зерна пшениці озимої (в середньому по всіх варіантах досліду за роки досліджень вона коливалась в межах 2,5-4,7 \%), що свідчить про те, що вносити таку дозу добрив не раціонально - вона може не окупитись відповідним збільшенням урожаю зерна. Більш ефективним під час вирощування пшениці на чорноземі звичайному в умовах Північного Степу виявилось удобрення грунту дозою добрив $\mathrm{N}_{30} \mathrm{P}_{60} \mathrm{~K}_{30}+\mathrm{N}_{30}$.

рослин на посівах зернових культур // Пропозиція. -2003 . - №4. - С. 56-57.

5. Наукові основи агропромислового виробництва в зоні Степу України / Редкол. : М. В. Зубець (голова редакційної колегії) [та ін.]. - К. : Аграрна наука. - 2004. - С. 9-18.

6. Пабат I. А., Коваленко В. Ю. Озима пшениця і їі удобрення на чорноземах в Степу // Агроогляд. - 2003. - №6 (21). - С. 33-35.

7. Пшениця озима в зоні Степу, кліматичні зміни та технології вирощування : монографія / А. В. Черенков, В. Г. Нестерець, М. М. Солодушко [та ін.]. - Дніпропетровськ : Нова ідеологія, 
2015. $-548 \mathrm{c}$

8. Сайко В. Ф. Наукові основи стійкого землеробства в Україні // Вісн. аграрн. науки. - №1. 2011. - C. 5-12.

9. Ходаніџький В., Ходаніџька О. Застосування ретардантів у посівах зернових культур. Пропозиція. URL : http://propozitsiya.com/ua

\section{ANNOTATION}

Pozniak V.V. Efficiency of application of growth regulator «Chlormequate-chloride» in winter wheat sowing depending on the level of fertilization.

The improvement of technology of growing of winter wheat allows to realize reserve of increase of her productivity. The aim of these researches was establishment of efficiency of complex application of treatment of seed or sowing of winter wheat of sort Spivanka by the growth regulator «Chlormequate-chloride» and different norms of fertilizer of soil by mineral fertilizers $\left(\mathrm{N}_{60} \mathrm{P}_{90} \mathrm{~K}_{60}+\mathrm{N}_{30}+\mathrm{N}_{30}\right.$, $\mathrm{N}_{30} \mathrm{P}_{60} \mathrm{~K}_{30}+\mathrm{N}_{30}, \mathrm{P}_{30} \mathrm{~K}_{20}+\mathrm{N}_{30}$ ) on a growth, development and forming of harvest of grain at growing on black earth ordinary in the conditions of North Steppe.

Treatment of seed or sowing of winter wheat influenced «Chlormequate-chloride» on growth, development and forming of harvest of grain during a spring-summer vegetation at application of all variants of fertilizer of soil. The higher level of harvest is got on a background the most $\left(\mathrm{N}_{60} \mathrm{P}_{90} \mathrm{~K}_{60}+\mathrm{N}_{30}+\mathrm{N}_{30}\right)$ and middle $\left(\mathrm{N}_{30} \mathrm{P}_{60} \mathrm{~K}_{30}+\mathrm{N}_{30}\right)$ dose of fertilizers. Application of different variants of treatment of «Chlormequate-chloride» provided /zastosuvannya-retardantiv-u-posivah-zernovih-

kultur (дата звернення - 14.01.2016).

10. Черенков А. В., Гирка А. Д. Шляхи підвищення зернової продуктивності озимої пшениці в умовах північної підзони Степу України // Бюл. Ін-ту зерн. госп-ва УААН. - Дніпропетровськ, 2005. - №23-24. - С. 36-39.

the increase of harvest of grain of winter wheat within the limits of 3.4-11.6\%.

We appeared the most effective variants of application of «Chlormequate-chloride»: treatment of growth regulator in autumn and one or double treatment in spring. Encrustation of seed by «Chlormequate-chloride» influenced positively on forming of harvest of grain of winter wheat also. Difference between variants with one or double treatment by «Chlormequate-chloride» additionally to treatment of sowing in autumn appeared insignificant (within the limits of error of experience).

Application of an increase dose of fertilizers $\left(\mathrm{N}_{60} \mathrm{P}_{90} \mathrm{~K}_{60}+\mathrm{N}_{30}+\mathrm{N}_{30}\right)$ in combination with the different variants of treatment of growth regulator did not provide the considerable increase of harvest of grain of winter wheat (on the average of all variants of experience for all years researches it hesitated within the limits of 2.5-4.7\%). At growing of wheat the fertilizer of soil appeared more effective by the dose of fertilizers of $\mathrm{N}_{30} \mathrm{P}_{60} \mathrm{~K}_{30}+\mathrm{N}_{30}$.

Key words: winter wheat, fertilization of soil, growth regulator "Chlormequate-chloride», structure of harvest, crop capacity. 